\title{
STAROZAVJETNA BIBLIJSKA BIBLIOGRAFIJA (2016.-2018.)
}

\author{
Karlo Višaticki - Tihonija Zovko
}

Sveučilište J. J. Strossmayera u Osijeku Katolički bogoslovni fakultet u Đakovu karlo.visaticki@djkbf.hr
UDK: 27-242(01)=163.42“2016/2018“ https://doi.org/10.34075/cs.55.1.7

Stručni rad

Rad zaprimljen 3/2019.

\section{Sažetak}

Prilog donosi, s malim iznimkama, starozavjetnu biblijsku bibliografiju na hrvatskom jeziku. Radi se o nastavku sličnih priloga koji su u „Crkvi u svijetu“ objavljeni 2016.g. Obrađuju se godišta 2016., 2017. te 2018. U ovom, prvom dijelu koji donosi starozavjetni dio, donosi se bibliografija iz ukupno petnaest (15) časopisa, te osim toga navode se rječnici, izdanja Svetog pisma, prigodna izdanja Biblije, monografije, nekoliko izdanja propovijedi koje po naravi stvari sadrže biblijsku tematiku. Posebno su navedeni zbornici, te pojedini prilozi u zbornicima, abecednim redom prezimena autora. Uključeni su prilozi iz stručnih časopisa (A1 i A2), koji imaju znanstveni karakter, te prilozi iz tjednika, odnosno mjesečnika koji imaju više divulgativan karakter. Prilog je podijeljen u devet (9) dijelova te donosi 1. rječnike (2 x); 2. izdanja Svetog pisma (7 x);3. prigodna izdanja Biblije (12 $x$ ); 4. četrnaest (14) monografija od devet (9) autora;5. četiri (4) zbirke propovijedi od trojice (3) autora; 6. devetnaest zbornika koji sadrže 7. pedeset (50) priloga od trideset šest (36) autora. Konačno imamo 8. priloge iz stručnih časopisa znanstvenog karaktera i to trideset tri (33) priloga od devetnaest (19) autora i 9. četrdeset pet (45) priloga iz tjednika, mjesečnika, „Biblije danas“, iz časopisa divulgativnog karaktera od dvanaest (12) autora. Cilj priloga je pomoći kolegicama i kolegama u struci, ali i svima koji cijene pisanu Riječ Božju, kako lakše i brže doći do sadržaja objavljenih u posljednje tri (3) godine.

Ključne riječi: Biblija, Stari zavjet, biblijska bibliografija, starozavjetna biblijska bibliografija, hrvatska biblijska bibliografija

\section{UVODNE NAPOMENE}

Bibliografske jedinice izdvojene su iz časopisa publiciranih $\mathrm{u}$ Hrvatskoj i Bosni Hercegovini: Biblija danas, Bogoslovska smotra, 
Bosna franciscana, Crkva u svijetu, Diacovensia, Kairos, Kana, Katolički tjednik, Nova prisutnost, Riječki teološki časopis, Služba Božja, Svjetlo riječi, Vjesnik Đakovačko-osječke nadbiskupije i Srijemske biskupije, Veritas, Vrhbosnensia.

\section{RJEČNICI / GRAMATIKE}

- POPOVIĆ, Anto, Grčko-hrvatski rječnik Novoga zavjeta sa statistikom grčkih riječi, Kršćanska sadašnjost, Zagreb, 2016.

- VUGDELIJA, Marijan, Gramatika hebrejskoga biblijskog jezika, Književni krug, Split, 2016.

\section{SVETO PISMO}

- Biblija / prijevod Stari zavjet (osim Petoknjižja i Psalama) na temelju rukopisa Antuna Sovića, Petoknjižje Silvije Grubišić, Psalmi Filibert Gass, Novi zavjet Ljudevit Rupčić; opći uvod u Bibliju, uvodi i napomene uz knjige Novoga zavjeta Bonaventura Duda; kazalo poznatijih imena Jerko Fućak; uvodi i napomene uz Petoknjižje, povijesne i proročke knjige Staroga zavjeta Ante Kresina; uvodi i napomene uz mudrosne knjige Staroga zavjeta Celestin Tomić; urednici Josip Tabak, Jerko Fućak], Zagreb, Kršćanska sadašnjost, 2016. [2.izd.]

- Biblija / [glavni urednici Jure Kaštelan, Bonaventura Duda; prijevod Stari zavjet (osim Petoknjižja i Psalama) na temelju rukopisa Antuna Sovića, Petoknjižje Silvije Grubišić, Psalmi Filibert Gass, Novi zavjet Ljudevit Rupčić ; suradnici: književni Branko Brusar ... [et al.], biblijski Bonaventura Duda ... [et al.], jezični Marko Grčić ... [et al.] ; popratni tekstovi Bonaventura Duda ... et al.], Zagreb, Kršćanska sadašnjost, 2016.[3. izd.]

- Biblija: Stari i Novi zavjet / Iprijevod Stari zavjet (osim Petoknjižja i Psalama) na temelju rukopisa Antuna Sovića, Petoknjižje Silvije Grubišić, Psalmi Filibert Gass, Novi zavjet Ljudevit Rupčić; suradnici književni: Branko Brusar ... [et al.], biblijski Bonaventura Duda ... [et al.], jezični Marko Grčić ... [et al.] ; popratni tekstovi Bonaventura Duda ... [et al.]; glavni urednici Jure Kaštelan, Bonaventura Duda], Zagreb, Kršćanska sadašnjost, 2018. [2.izd., 4.izd.]

- Biblija: Stari i Novi Zavjet: bez deuterokanonskih knjiga /[prijevod Stari zavjet (osim Petoknjižja i Psalama) na temelju ruko- 
pisa Antuna Sovića, Petoknjižje Silvije Grubišić, Psalmi Filibert Gass, Novi zavjet Ljudevit Rupčić]; urednici Josip Tabak, Jerko Fućak, KS, Zagreb, 2017. [Posebno izdanje]

- Biblija / [prijevod Stari zavjet (osim Petoknjižja i Psalama) na temelju rukopisa Antuna Sovića, Petoknjižje Silvije Grubišić, Psalmi Filibert Gass, Novi zavjet Bonaventura Duda, Jerko Fućak; suradnici: književni Branko Brusar ... [et al.], biblijski Bonaventura Duda ... [et al.], jezični Marko Grčić ... [et al.] ; popratni tekstovi Bonaventura Duda ... [et al.]; glavni urednici Jure Kaštelan, Bonaventura Duda], Zagreb, Kršćanska sadašnjost, 2018. [4.izd.]

- Biblija Plus / [glavni urednik Izvorne Full Life Study Bible Donald C. Stamps]; Springfield : Life Publishers International, 2018.

- Jeruzalemska Biblija: Stari i Novi zavjet s bilješkama iz „La Bible de Jérusalem" / [uredili Adalbert Rebić, Jerko Fućak i Bonaventura Duda], KS, Zagreb, 2017. (9. izd.)

- Psalmi: na gradiščanskohrvatskom jeziku /[glavni urednik Danijel Berković; preveli Augustin Blazovich, Stefan Geosits, Branko Kornfeind ], Biblijski institut, Zagreb, 2018.

- Psalmi: 1816/[prijevod Antun Vrančić]; [glavni urednik DanijelBerković], Biblijski institut: Hrvatsko biblijsko društvo, Zagreb, 2017.

- Sveto pismo Starog' i Novog' zakona / preveo Matija Petar Katančić, Hrvatsko biblijsko društvo, Zagreb; Synopsis, Sarajevo; Naša Ognjišta: Tomislavgrad, 2016., XVII, 1360 str. (Napomena: Popravljeno izdanje pripremili Marko Tomić, Ivan Jurčević, Karlo Višaticki.)

\section{PRigodna IZDANJA BibliJe}

- $\quad$ AMIOT, Karine-Marie, Biblija za najmanje, Verbum, Split, 2017.

- AMIOT, Karine-Marie, Ilustrirana Biblija za djecu, Verbum, Split, 2017.

- $\quad$ AMOUR, Michael C., Biblija za djecu, Biblijski institut, Zagreb, 2017. [novo izmijenjeno izd.]

- Biblija: čitaj, traži i nauči / [tekst Guy David Stancliff; ilustracije Sandrine L'amour ; prijevod Ivan Peroš], Split, Verbum, 2017.

- Biblija za mlade /[priredio Bernard Meuser; prijevod popratnih tekstova Franjo Frankopan Volić], Verbum, Split, 2016.

- Biblija za mlade s predgovorom pape Franje /[priredio Bernard Meuser; prijevod popratnih tekstova Franjo Frankopan Volić], Verbum, Split, 2016. (2. izd. 2017.) 
- Biblija: ključne poruke i pouke: 22 poticajna biblijska citata protumačena poznatim biblijskim pričama / Cecille Fodor, Vanessa Carroll; ilustracije Fabiano Fiorin; prijevod Ivan Peroš, Verbum, Split, 2017.

- $\quad$ DAVID, Juliet, Biblija za malene, Verbum, Split, 2016. [5. izd.]

- Ilustrirana Biblija mladih / [američko originalno izdanje sastavili Josip E. Krause i Samuel Ternen; s grčkog izvornika preveo Bonaventura Duda], KS, Zagreb, 2017.(26. izd. )

- Ilustrirana Biblija za mlade / ilustrirao Zbigniew Freus Iprijevod Ivan Šarić], Verbum, Split, (4. izd.)

- $\quad$ MEDIANI, Rosa, Biblija za velike i male, Salesiana, Zagreb, 2018.

- Velika ilustrirana Biblija: s dodatnim objašnjenjima/ [glavni urednik Zoran Manjković; preveo s engleskog Mladen Juričić], Mozaik knjiga, Zagreb, 2017.

\section{MonografiJe}

- $\quad$ CRVENKA, Mario, Muževi u Bibliji, Teovizija, Zagreb, 2017.

- HEINZ, Hans, Suvremeni čovjek i Biblija, Znaci vremena, Zagreb, 2016. (prijevod Milan Šušljić)

- LUJIĆ, Božo, Svijet i čovjek s gledišta Biblije, Svjetlo riječi, Sarajevo, 2016.

- LUJIĆ, Božo, Tragovima biblijskih prostora i događaja: biblijskoteološki i povijesno-arheološki uvidi i poruke, Kršćanska sadašnjost, Zagreb, 2016. [2. izd. 2018.]

- LUJIĆ, Božo, Biblijsko svjetlo na putu života: biblijske teme vezane uz egzistenciju suvremenog čovjeka, Kršćanska sadašnjost, Zagreb, 2018.

- LUJIĆ, Božo, Hrvatski standardni prijevod Biblije: tradicijska podloga, lingvistička načela i prevedeni tekstovi, Hrvatsko biblijsko društvo, Zagreb, 2018.

- MRAKOVČIĆ, Božidar, Biblijska pitanja, KS, Zagreb, 2018.

- MUŽIĆ, Josip, Ilija gromounik: prorok posljednjih vremena, Glas Koncila, Zagreb, 2017. [2. promijenjeno izd. 2018.]

- PARDON, Đurica, Teologija zemlje u metaforici proroka Hošee, Glas Koncila, Zagreb, 2017.

- SLAVIĆ, Dean, Biblija kao književnost, Školska knjiga, Zagreb, 2017.

- $\quad$ TEPERT, Darko, Riječ o milosrđu: molitveno čitanje biblijskih tekstova o milosrđu, Teovizija, Zagreb, 2016. 
- TOMAŠEVIĆ, Darko, Sveta zemlja: povijesno-duhovni pratitelj, Glas Koncila, Zagreb: Katolički bogoslovni fakultet, Sarajevo, 2017.(3. dopunjeno i proš. izd.)

\section{PROPOVIJEDI}

- LUJIĆ, Božo, Naviještati Boga milosrđa u današnjem vremenu: propovijedi za svetkovine i blagdane, Kršćanska sadašnjost, Zagreb, 2016.

- KARLIĆ, Ivan, Osluškujući Božju riječ...: homilije za godinu B, Kršćanska sadašnjost, Zagreb, 2017.

- KARLIĆ, Ivan, Osluškujući Božju riječ...: homilije za godinu C, Kršćanska sadašnjost, Zagreb, 2018.

- TEPERT, Darko, Uziđimo na Goru Gospodnju: tumačenja nedjeljnih i blagdanskih čitanja u godini A došašće, božićno vrijeme, korizma, vazmeno vrijeme, Teovizija, Zagreb, 2017.

\section{ZBORNICI}

- Bogu-gospodaru i ljubitelju života (Mudr 11,26). Zbornik u čast prof. dr. sc. Nikole Hohnjeca povodom 70. godine života, [uredili Božo Lujić, Darko Tepert], KS, Zagreb, 2016.

- Božje postojanje i Božji atributi [uredio Tvrtko Jolić], Institut za filozofiju i Udruga za promicanje filozofije, Zagreb, 2017.

- O Božjem milosrđu: zbornik radova s Međunarodnoga znanstvenog simpozija o milosrđu održanog 22. travnja 2016. godine na Katoličkom bogoslovnom fakultetu u Đakovu Sveučilišta Josipa Jurja Strossmayera u Osijeku, [uredili Ivica Raguž, Šimo Šokčević], Katolički bogoslovni fakultet, Đakovo, 2016.

- Challenges to Religious Education in Contemporary Society, [edited by Jadranka Garmaz and Alojzije Čondić], Crkva u svijetu, Split, 2017.

- Čovjek i smrt. Teološki, filozofski, bioetički i društveni pristup [uredili Gordan Črpić...<et al.], Institut društvenih znanosti Ivo Pilar; Hrvatsko katoličko sveučilište; Udruga Posmrtna pomoć, Zagreb, 2017.

- Domovinski rat i njegovi društveno-ekonomski odrazi na razvoj hrvatskog Istoka [glavni urednik Miljenko Brekalo], Institut društvenih znanosti Ivo Pilar, Zagreb, 2016. 
- Ecce homo! Medicinski i teološki pristupi. Zbornik radova znanstvenog skupa, Split, 16. ožujka 2018.,[uredio Ante Mateljan], CuS, Split, 2018.

- Gospi Tekijskoj. Zbornik radova s Međunarodnoga znanstvenog simpozija prigodom 300. obljetnice svetišta Gospe Tekijske održanog 20. i 21. svibnja 2016. u Petrovaradinu / [uredili Darija Damjanović Barišić, Ivica Raguž, Boris Vulić], Katolički bogoslovni fakultet, Đakovo, 2017.

- I vangeli della misericordia [ a cura di Giulio Michelini], Ancora, Milano, 2016.

- Ima li u ekonomiji mjesta za milosrđe?, [uredio Ivan Koprek], FTI, Zagreb, 2016.

- $\quad$ Numeri Secondi. Il volto di Dio attraverso il volto dei piccoli. Scritti in onore del prof. don Massimo Grilli in occasione del suo $70^{\circ} \mathrm{com}-$ pleanno, [uredili Maurizio Guidi, Stefano Zeni], GBP, Roma, 2018.

- Oprost i pomirenje: krilatice lišene sadržaja? Zbornik radova Simpozij, Sarajevo, 21.-22. rujna 2017. [uredili Zorica Maros, Darko Tomašević], Katolički bogoslovni fakultet, Sarajevo; Glas Koncila, Zagreb, 2018.

- Poslovna etika i demografska politika,[uredio Ivan Koprek], FTI, Zagreb, 2017.

- Poziv, poslanje i služenje. Pedeset godina svećeništva Tomislava Šporčića, [uredio Ivan Šporčić], Gospićko-senjska biskupija, Gospić, 2017.

- Prorok Ilija. Zbornik radova o sv. Iliji u povodu 10. obljetnice Samostana - duhounog centra Karmel sv. Ilije 2006.-2016. [uredio Jure Zečević ], HIZ, Zagreb, 2016.

- Tridentska baština: katolička obnova i konfesionalizacija u hrvatskim zemljama [urednice izdanja Zrinka Blažević, Lahorka Plejić Poje], Matica hrvatska; Katolički bogoslovni fakultet; Filozofski fakultet Družbe Isusove, Zagreb, 2016.

- Tko su bili hrvatski prevoditelji Biblije?: zbornik radova znanstvenog simpozija, Zagreb, 2013., [urednik Danijel Berković], Biblijski institut, Zagreb, 2018.

- Zagrebačka Biblija: znanstveni simpozij o 40. obljetnici (1968.2008.) Zagreb, 24. i 25. listopada 2008. [priredio Anton Šuljić], KS, Zagreb, 2018.

- Znat će da prorok bijaše među njima!(Ez 33,33): zbornik u čast prof. dr. sc. Bože Lujića, OFM, povodom 70. godine života [uredili Stipo Kljajić, Mario Cifrak], Zagreb: Kršćanska sadašnjost - Katolički bogoslovni fakultet Sveučilišta u Zagrebu; Sarajevo: Franjevačka teologija, 2018. 


\section{PRILOZI U ZBORNICIMA}

- BARŠČEVSKI, Taras, Usporedba mjera i novca u hrvatskim biblijskim prijevodima (Zagrebačka Biblija, Šarićeva Biblija, Varaždinska Biblija i Franjevačka Biblija), u: Znat će da prorok bijaše među njima (Ez 33,33). Zbornik u čast prof. dr. sc. Bože Lujića, OFM, povodom 70. godine života, [uredili Stipo Kljajić, Mario Cifrak], KS, Zagreb, 2018., 535-578.

- $\quad$ BECK, Boris, Neotklonjive aporije zbog kojih se biblijski prijevodi međusobno razlikuju, u: Tko su bili hrvatski prevoditelji Biblije?: zbornik radova znanstvenog simpozija, Zagreb, 2013., [urednik Danijel Berković], Biblijski institut, Zagreb, 2018., 15-33.

- BERKOVIĆ, Danijel, Anatomski idiom u pobožnostibiblijskih psalmista, u: Znat će da prorok bijaše među njima (Ez 33,33). Zbornik u čast prof. dr. sc. Bože Lujića, OFM, povodom 70. godine života, [uredili Stipo Kljajić, Mario Cifrak], KS, Zagreb, 2018., 113-130.

- $\quad$ BERKOVIĆ, Danijel, Biblijski Psaltir kao Ars moriendi, u: Čovjek i smrt. Teološki, filozofski, bioetički $i$ društveni pristup [uredili Gordan Črpić...<et al.], Institut društvenih znanosti Ivo Pilar; Hrvatsko katoličko sveučilište; Udruga Posmrtna pomoć, Zagreb, 2017., 189-205.

- BERKOVIĆ, Danijel, Biskup Maksimilijan Vrhovac i njegova Biblija, u: Tko su bili hrvatski prevoditelji Biblije?: zbornik radova znanstvenog simpozija, Zagreb, 2013., [urednik Danijel Berković], Biblijski institut, Zagreb, 2018., 35-59.

- $\quad$ BOTICA, Stipe, Veza Biblije i hrvatske kulturne tradicije, u: Zagrebačka Biblija: znanstveni simpozij o 40. obljetnici (1968.2008). Zagreb, 24. i 25. listopada 2008. [priredio Anton Šuljić], KS, Zagreb, 2018., 91-107.

- BRNČIĆ, Jadranka, Prijevod Biblije - hermeneutički i kulturni događaj, u: Zagrebačka Biblija: znanstveni simpozij o 40. obljetnici (1968.-2008). Zagreb, 24. i 25. listopada 2008. [priredio Anton Šuljić], KS, Zagreb, 2018., 79-90.

- $\quad$ CHALUPA, Petr, Die Rezeption der normativen Texte des Pentateuchs in den Büchern Esra und Nehemia, u: Bogu - gospodaru i ljubitelju života (Mudr 11,26). Zbornik u čast prof. dr. sc. Nikole Hohnjeca povodom 70. godine života, [uredili Božo Lujić, Darko Tepert], KS, Zagreb, 2016., 87-107.

- $\quad$ CIFRAK, Mario, Ivan Evanđelist Šarić iZagrebačka Biblija. Tekstualno-kritički problemi prijevoda, u: Zagrebačka Biblija: znanstveni simpozij o 40. obljetnici (1968.-2008). Zagreb, 24. i 25. listopada 2008. [priredio Anton Šuljić], KS, Zagreb, 2018., 145-154. 
- CIFRAK, Mario, Zagrebačka Biblija (1968.). Novi prijevod cijele Biblije na hrvatski, zajedničko je djelo teologa, filologa i književnika, u: Tko su bili hrvatski prevoditelji Biblije?: zbornik radova znanstvenog simpozija, Zagreb, 2013., [urednik Danijel Berković], Biblijski institut, Zagreb, 2018., 75-87.

- $\quad$ DA DON, Kotel, Smrt i duša - bioetika u židovstuu. Odnos judaizma prema tijelu i prema duši u starozavjetnim spisima Biblije, u židouskome pravu i u rabinskoj literaturi, u: Čovjek $i$ smrt. Teološki, filozofski, bioetički i društveni pristup [uredili Gordan Črpić...<et al.>], Institut društvenih znanosti Ivo Pilar; Hrvatsko katoličko sveučilište; Udruga Posmrtna pomoć, Zagreb, 2017., 115-141.

- FARKAŠ, Loretana, Katančićev prijevod Biblije i Zagrebačka Biblija, u: : Zagrebačka Biblija: znanstveni simpozij o 40. obljetnici (1968.-2008). Zagreb, 24. i 25. listopada 2008. [priredio Anton Šuljić], KS, Zagreb, 2018., 109-130.

- GOLUB, Ivan, Sjećanja i zastupanja (terminološki prijepori) o Zagrebačkoj Bibliji, u: Zagrebačka Biblija: znanstveni simpozij o 40. obljetnici (1968.-2008). Zagreb, 24. i 25. listopada 2008. [priredio Anton Šuljić], KS, Zagreb, 2018., 21-38.

- GRČIĆ, Marko, Biblija i 1968., u: Zagrebačka Biblija: znanstveni simpozij o 40. obljetnici (1968.-2008). Zagreb, 24. i 25. listopada 2008. [priredio Anton Šuljić], KS, Zagreb, 2018., 39-46.

- $\quad$ HAUSMANN, Jutta, Hoffnung in unruhigen Zeiten- Überlegungen zu Psalm 140, u: Znat će da prorok bijaše među njima (Ez 33,33). Zbornik u čast prof. dr. sc. Bože Lujića, OFM, povodom 70. godine života, [uredili Stipo Kljajić, Mario Cifrak], KS, Zagreb, 2018., 101-112.

- HENTSCHEL, Georg, Der Gottesmann aus Juda und der Prophet aus Bet-El (1 Kön, 13, 11-32a), u: Bogu-gospodaru i ljubitelju života (Mudr 11,26). Zbornik u čast prof. dr. sc. Nikole Hohnjeca povodom 70. godine života, [uredili Božo Lujić, Darko Tepert], KS, Zagreb, 2016., 71-86.

- HOHNJEC, Nikola, Apokrifne apokalipse uz Stari zavjet, u: Znat će da prorok bijaše među njima (Ez 33,33). Zbornik u čast prof. dr. sc. Bože Lujića, OFM, povodom 70. godine života, [uredili Stipo Kljajić, Mario Cifrak], KS, Zagreb, 2018., 247-263.

- HOŠKO, Emanuel, Izdavanje Katančićeva prijevoda Svetoga Pisma i Čevapović, u: Znat će da prorok bijaše među njima (Ez 33,33). Zbornik u čast prof. dr. sc. Bože Lujića, OFM, povodom 70. godine života, [uredili Stipo Kljajić, Mario Cifrak], KS, Zagreb, 2018., 591-604. 
- JAMBREK, Stanko, Prijevodi Biblije na hrvatski jezik i hrvatske protestantske knjige tijekom i nakon tridentinskog koncila, u: Tridentska baština: katolička obnova i konfesionalizacija u hrvatskim zemljama [urednice izdanja Zrinka Blažević, Lahorka Plejić Poje], Matica hrvatska; Katolički bogoslovni fakultet; Filozofski fakultet Družbe Isusove, Zagreb, 2016., 409-425.

- JELIČIĆ, Anđela, The Force of God's Promise vs. The Violence of Man. Narrative Proceedings in Jeremiah 19,14-20,18, u: Bogu - gospodaru i ljubitelju života (Mudr 11,26). Zbornik u čast prof. dr. sc. Nikole Hohnjeca povodom 70. godine života, [uredili Božo Lujić, Darko Tepert], KS, Zagreb, 2016., 127-143.

- KARLIĆ, Ivan - GELO, Milan, Milosrđe kao „zaboravljeni“ Božji atribut u kršćanskome shvaćanju Božje opstojnosti, u: Božje postojanje i Božji atributi [uredio Tvrtko Jolić], Institut za filozofiju i Udruga za promicanje filozofije, Zagreb, 2017., 129-146.

- KATIČIĆ, Radoslav, Uz 40 godina Zagrebačke Biblije, u: Zagrebačka Biblija: znanstveni simpozij o 40. obljetnici (1968.-2008). Zagreb, 24. i 25. listopada 2008. [priredio Anton Šuljić], KS, Zagreb, 2018., 63-67.

- KLJAJIĆ, Stipo, Joabova uloga u Davidovu ubojstvu Urije Hetita. Narativna analiza i vrednovanje uloge Joaba u 2 Sam 11, 1-27, u: Znat će da prorok bijaše među njima (Ez 33,33). Zbornik u čast prof. dr. sc. Bože Lujića, OFM, povodom 70. godine života, [uredili Stipo Kljajić, Mario Cifrak], KS, Zagreb, 2018., 51-75.

- KNEZOVIĆ, Katica, Nastanak i prihvat Zagrebačke Biblije, u: Zagrebačka Biblija: znanstveni simpozij o 40. obljetnici (1968.2008). Zagreb, 24. i 25. listopada 2008. [priredio Anton Šuljić], KS, Zagreb, 2018., 51-62.

- KNEŽEVIĆ, Ruben, Rimska izdanja Karadžićevih „Evanđelja“. Okolnosti izdavanja i crkvenopolitička obilježja Karadžićevih „Evanđelja“ izdanih 1943. i 1947. u Rimu u katoličkoj verziji, u: Tko su bili hrvatski prevoditelji Biblije?: zbornik radova znanstvenog simpozija, Zagreb, 2013., [urednik Danijel Berković], Biblijski institut, Zagreb, 2018., 89-129.

- $\quad$ KRAŠOVEC, Jože, Izkušnja, sinteza in vidiki besede $v$ Stari zavezi, u: Bogu - gospodaru i ljubitelju života (Mudr 11,26). Zbornik $u$ čast prof. dr. sc. Nikole Hohnjeca povodom 70. godine života, [uredili Božo Lujić, Darko Tepert], KS, Zagreb, 2016., 267-280.

- KRAŠOVEC, Jože, Semantics of righteousness of God in the Hebrew Bible, u: Znat će da prorok bijaše među njima (Ez 33,33). Zbornik u čast prof. dr. sc. Bože Lujića, OFM, povodom 70. godine života, [uredili Stipo Kljajić, Mario Cifrak], KS, Zagreb, 2018., 215-234. 
- $\quad$ KUZMIČ, Peter, Sveto pismo za hrvatski narod: ekumensko-jezikoslovni izazovi prve kroatizacije Vuk-Daničićeva prijevoda Biblije, u: Zagrebačka Biblija: znanstveni simpozij o 40. obljetnici (1968.-2008). Zagreb, 24. i 25. listopada 2008. [priredio Anton Šuljić], KS, Zagreb, 2018., 131-144.

- LUJIĆ, Božo, Biblijska interpretacija obrambenoga rata i motiv sjećanja. Egzegetsko-teološka analiza Izl 8-16, u: Domovinski rat i njegovi društveno-ekonomski razvoj hrvatskog Istoka, [glavni urednik Miljenko Brekalo], Institut društvenih znanosti Ivo Pilar, Zagreb, 2016., 107-119.

- LUJIĆ, Božo, Novi savez kao novi odnos univerzalne komunikacije. Egzegetsko-teološka analiza Hoš 2, 18-25, u: Bogu - gospodaru i ljubitelju života (Mudr 11,26). Zbornik u čast prof. dr. sc. Nikole Hohnjeca povodom 70. godine života, [uredili Božo Lujić, Darko Tepert], KS, Zagreb, 2016., 145-163.

- MALY, Anđelo, Glagol bhl i pitanje njegova kasnog podrijetla, u: Znat će da prorok bijaše među njima (Ez 33,33). Zbornik u čast prof. dr. sc. Bože Lujića, OFM, povodom 70. godine života, [uredili Stipo Kljajić, Mario Cifrak], KS, Zagreb, 2018., 203-213.

- MARIJANOVIĆ, Luka, Nek' se osuši desnica moja, Jeruzaleme, ako tebe zaboravim,! (Ps 137,3), u: Znat će da prorok bijaše među njima!(Ez 33,33): zbornik u čast prof. dr. sc. Bože Lujića, OFM, povodom 70. godine života [uredili Stipo Kljajić, Mario Cifrak], Zagreb: Kršćanska sadašnjost: Katolički bogoslovni fakultet Sveučilišta u Zagrebu; Sarajevo: Franjevačka teologija, 2018., 77-99.

- PALMISANO, Maria Carmela, La riflessione sulla storia in Ben Sira, u: Znat će da prorok bijaše među njima (Ez 33,33). Zbornik u čast prof. dr. sc. Bože Lujića, OFM, povodom 70. godine života, [uredili Stipo Kljajić, Mario Cifrak], KS, Zagreb, 2018., 189-201.

- PALMISANO, Maria Carmela, Lo sguardo di Dio nel libro del Siracide: immagini e contesti, u: Bogu - gospodaru i ljubitelju života (Mudr 11,26). Zbornik u čast prof. dr. sc. Nikole Hohnjeca povodom 70. godine života, [uredili Božo Lujić, Darko Tepert], KS, Zagreb, 2016., 109-126.

- PARDON, Đurica, Očne bolesti kod starozavjetnih osoba. Jesu li im mogle pomoći naočale?, u: Bogu - gospodaru i ljubitelju života (Mudr 11,26). Zbornik u čast prof. dr. sc. Nikole Hohnjeca povodom 70. godine života, [uredili Božo Lujić, Darko Tepert], KS, Zagreb, 2016., 343-364.

- PARDON, Đurica, Zemlja: Izraelova i Božja baština. Teologija zemlje u predsužanjsih proroka, u: Znat će da prorok bijaše 
među njima (Ez 33,33). Zbornik u čast prof. dr. sc. Bože Lujića, OFM, povodom 70. godine života, [uredili Stipo Kljajić, Mario Cifrak], KS, Zagreb, 2018., 153-172.

- $\quad$ POPOVIĆ, Anto, Kronologija pretpotopnog (Post 5,3-32) i postpotopnog (Post 1 1,10-32) rodoslovlja prema tri tekstualne varijante: $M T$, SP i LXX, u: Znat će da prorok bijaše među njima (Ez 33,33). Zbornik u čast prof. dr. sc. Bože Lujića, OFM, povodom 70. godine života, [uredili Stipo Kljajić, Mario Cifrak], KS, Zagreb, 2018., 29-51.

- POPOVIĆ, Anto, Pitanje funkcije Post 2,4a i Post 2, 4b, u: Bogu - gospodaru i ljubitelju života (Mudr 11,26). Zbornik u čast prof. dr. sc. Nikole Hohnjeca povodom 70. godine života, [uredili Božo Lujić, Darko Tepert], KS, Zagreb, 2016., 11-25.

- PRELEVIĆ, Luciano Moše / BREGOVIĆ PRAČIĆ, Rozalija, Plodite se, i množite... (Postanak 1, 28), u: Poslouna etika i demografska politika [uredio Ivan Koprek], FTI, Zagreb, 2017., 125-133.

- $\quad$ REBIĆ, Adalbert, Antun Sović, osporavani prevoditelj Biblije, u: Tko su bili hrvatski prevoditelji Biblije?: zbornik radova znanstvenog simpozija, Zagreb, 2013., [urednik Danijel Berković], Biblijski institut, Zagreb, 2018., 131-144.

- $\quad$ REBIĆ, Adalbert, Biblija - što je to?, u: Tko su bili hrvatski prevoditelji Biblije?: zbornik radova znanstvenog simpozija, Zagreb, 2013., [urednik Danijel Berković], Biblijski institut, Zagreb, 2018., 7-14.

- $\quad$ RUNJE, Domagoj, Parents and children on the furst pages of the Bible (Gen 1-12), u: Challenges to Religious Education in Contemporary Society [edited by Jadranka Garmaz and Alojzije Čondić], Crkva u svijetu, Split, 2017., 11-21.

- RUNJE, Domagoj, Rukopisi Hramskoga svitka, u: Znat će da prorok bijaše među njima (Ez 33,33). Zbornik u čast prof. dr. sc. Bože Lujića, OFM, povodom 70. godine života, [uredili Stipo Kljajić, Mario Cifrak], KS, Zagreb, 2018., 265-275.

- SCHMATOVICH, Janos, Die Stellung des Dekalogs im Gottes Bund, u: Bogu - gospodaru i ljubitelju života (Mudr 1 1,26). Zbornik u čast prof. dr. sc. Nikole Hohnjeca povodom 70. godine života, [uredili Božo Lujić, Darko Tepert], KS, Zagreb, 2016., 49-70.

- ŠPORČIĆ, Ivan, Pozvan životom pozivati. Biblijsko-ekleziološka dimenzija proroštva, u: Bogu - gospodaru i ljubitelju života (Mudr 11,26). Zbornik u čast prof. dr. sc. Nikole Hohnjeca povodom 70. godine života, [uredili Božo Lujić, Darko Tepert], KS, Zagreb, 2016., 281-295.

- TEPERT, Darko, Židovska dijaspora u grčko-rimskom svijetu od 3. st. pr. Kr. do 2. st. po Kr., u: Bogu-gospodaru i ljubitelju života 
(Mudr 11,26). Zbornik u čast prof. dr. sc. Nikole Hohnjeca povodom 70. godine života, [uredili Božo Lujić, Darko Tepert], KS, Zagreb, 2016., 461-475.

- TEPERT, Darko, Razdoblje početaka djelovanja proroka: podijeljeno kraljeustvo, u: Znat će da prorok bijaše među njima (Ez 33,33). Zbornik u čast prof. dr. sc. Bože Lujića, OFM, povodom 70. godine života, [uredili Stipo Kljajić, Mario Cifrak], KS, Zagreb, 2018., 131-152.

- TURALIJA, Dubravko, Koheletov hevelizam u odnosu na oprost $i$ pomirenje, u: Oprost i pomirenje: krilatice lišene sadržaja? Zbornik radova Simpozij, Sarajevo, 21.-22. rujna 2017. [uredili Zorica Maros, Darko Tomašević], Katolički bogoslovni fakultet, Sarajevo; Glas Koncila, Zagreb, 2018., 91-121.

- TURALIJA, Dubravko, Proročki termin „gorjeti“, u: Znat će da prorok bijaše među njima (Ez 33,33). Zbornik u čast prof. dr. sc. Bože Lujića, OFM, povodom 70. godine života, [uredili Stipo Kljajić, Mario Cifrak], KS, Zagreb, 2018., 173-187.

- VELČIĆ, Bruna, Umijeće biblijske naracije: analiza pripovjedačkog zapleta Post 42,1-38, u: Bogu-gospodaru i ljubitelju života (Mudr 11,26). Zbornik u čast prof. dr. sc. Nikole Hohnjeca povodom 70. godine života, [uredili Božo Lujić, Darko Tepert], KS, Zagreb, 2016., 27-47.

- VELČIĆ, Bruna, Ljudsko stvorenje prema hebrejskoj terminologiji uPost 1-2, u: Znat će da prorok bijaše među njima (Ez 33,33). Zbornik u čast prof. dr. sc. Bože Lujića, OFM, povodom 70. godine života, [uredili Stipo Kljajić, Mario Cifrak], KS, Zagreb, 2018., 11-27.

- VIŠATICKI, Karlo, Starozavjetni Bog milosrđa?, u: O Božjem milosrđu: zbornik radova s Međunarodnoga znanstvenog simpozija o milosrđu održanog 22. travnja 2016. godine na Katoličkom bogoslovnom fakultetu u Đakovu Sveučilišta Josipa Jurja Strossmayera u Osijeku, [uredili Ivica Raguž, Šimo Šokčević], Katolički bogoslovni fakultet, Đakovo, 2016.,23-35.

- VIŠATICKI, Karlo, Lik Mojsija prema Josipu Flaviju, u: Bogu gospodaru i ljubitelju života. (Mudr 11,26). Zbornik u čast prof. dr. sc. Nikole Hohnjeca povodom 70. godine života, (uredili Božo Lujić, Darko Tepert), KS, Zagreb 2016., 477-490.

- VIŠATICKI, Karlo, Bog se ljuti-Bog se kaje, u: Znat će da prorok bijaše među njima!(Ez 33,33): zbornik u čast prof. dr. sc. Bože Lujića, OFM, povodom 70. godine života [uredili Stipo Kljajić, Mario Cifrak], Zagreb: Kršćanska sadašnjost: Katolički bogoslovni fakultet Sveučilišta u Zagrebu; Sarajevo: Franjevačka teologija, 2018., 235-245. 
- VIŠATICKI, Karlo, Matija Petar Katančić- fragmenti iz života $i$ djela, u: Tko su bili hrvatski prevoditelji Biblije?: zbornik radova znanstvenog simpozija, Zagreb, 2013., [urednik Danijel Berković], Biblijski institut, Zagreb, 2018., 145-163.

- ZOVKIĆ, Mato, Iskustvo prevođenja i pisanja u Šarićevu prijevodu Biblije 1940.-1943., u: Tko su bili hrvatski prevoditelji Biblije?: zbornik radova znanstvenog simpozija, Zagreb, 2013., [urednik Danijel Berković], Biblijski institut, Zagreb, 2018., 165-181.

\section{PRILOZI IZ STRUČNIH ČASOPISA ZNANSTVENOG KARAKTERA $(\mathrm{A} 1, \mathrm{~A} 2 \ldots)$}

- $\quad$ BAJIĆ, Monika, Autorstvo Petoknjižja (Tora), Kairos, 10 (2016.) 2, 213-221.

- BARŠČEVSKI, Taras, Prorok Knjige Otkrivenja, Bogoslouska smotra, 86 (2016.) 4, 795-812.

- BERKOVIĆ, Danijel, Brak i bračne razmirice u Starom zavjetu, Kairos, 12 (2018.) 2, 181-200.

- DA-DON, Agnes Eva - DA-DON, Kotel, Salomonova presuda - jezična analiza i interpretacija (1 Kr 3, 16-28), Nova prisutnost, 15 (2017.) 1, 47-67.

- DA-DON, Agnes Eva, Stav judaizma prema životinjama u starozavjetnim spisima Biblije, u židovskome pravu i u rabinskoj literaturi, Nova prisutnost, 16 (2018.) 3, 453-475.

- DA-DON, Kotel, Stav prema spašavanju života u židovskom zakonu: Milosrdni Samarijanac - ideal ili dužnost, moralna ili pravna obveza, Nova prisutnost, 15 (2017.) 3, 393-423.

- DA-DON, Kotel, Rođenje kralja Davida u mističnoj rabinskoj literaturi, Crkva u svijetu, 53 (2018.) 4, 575-601.

- DA-DON, Kotel, Uloga žene u židovskom braku u starozavjetnim spisima Biblije, u židovskom pravu i u rabinskoj literaturi, Kairos, 12 (2018.) 2, 141-167.

- DOMAŠ, Jasminka, Iskustvo i pojam stida u židovstvu, Crkva u svijetu, 51 (2016.) 3, 529-544.

- LUJIĆ, Božo, Vjera kao povijesna snaga i egzistencijalni temelj života: teološko-egzegetska analiza Iz 7,9b, Vrhbosnensia, 17 (2017.) 2, 357-377.

- LUJIĆ, Božo, Analiza Elizejeva čudesnoga djelovanja u povijesno-političkom području: odnos povijesnih činjenica i teološke nadgradnje, Riječki teološki časopis, 25 (2017.) 2 (50), 277-296. 
- LUJIĆ, Božo, Proroštvo i apokaliptika. Analitičko-komparativni pristup: sličnosti i razlike, Bogoslovska smotra, 87 (2017.) 2, 185-210.

- MALY, Anđelo, Neke crtice o starozavjetnoj eshatologiji, Bogoslouska smotra, 87 (2017.) 2, 303-326.

- MALY, Anđelo, Ples, igra, borba ili trka za vjeru: sportski jezik kao starozavjetna biblijska metafora, Nova prisutnost, 16 (2018.) 1, 59-71.

- MEDVED, Goran, Božje očinstvo u Starom zavjetu, Kairos, 10 (2016.) 2, 201-212.

- NEAGOE, Alexandru, Simboli sukoba i nade: uvodna analiza simbolizma iz knjiga Daniel i Otkrivenje, Kairos, 11 (2017.) 2, 199-207.

- ODRLJIN, Miljenko, Biti braća: zadaća i izazov. Varijacije na temu bratstvo u knjizi Postanka, Služba Božja, 56 (2016.) 1, 5-21.

- ODRLJIN, Miljenko, Ljubav prema Bogu kao prva zapovijed ljubavi u Bibliji, Služba Božja, 56 (2016.) 2-4, 123-137.

- PARDON, Đurica, Biblijska teologija zemlje - potka enciklike Laudato si, Diacovensia, 24 (2016.) 1, 13-43.

- PARDON, Đurica, Ima li nade za zemlju i njezine stanovnike?: poruka velike i male apokalipse proroka Izaije čitana svjetlom teologije zemlje u mraku ekološke krize (Iz 24 - 27; 34 - 35), Bogoslouska smotra, 87 (2017.) 2, 211-237.

- POPOVIĆ, Anto, Stvaranje čovjeka i izgon iz zemaljskog raja (Post $2,4-3,24)$. Starije (dijakronijsko) i novije (sinkronijsko) tumačenje biblijskog teksta, Bogoslouska smotra, 86 (2016.) 1, 91-113.

- POPOVIĆ, Anto, Doprinos dr. fra Ljudevita Rupčića tumačenju dogmatske konstitucije Dei Verbum, Bosna franciscana, 36 (2018.) 49, 45-58.

- $\quad$ RUNJE, Domagoj, Stid u Post 2,25-3,21, Crkva u svijetu, 51 (2016.) 3, 396-412.

- $\quad$ RUNJE, Domagoj, Apokaliptika u izvornim Kumranskim spisima, Bogoslovska smotra, 87 (2017.) 2, 271-285.

- ŠARČEVIĆ, Ivan, Ostati ili odseliti? Pastoralno-teološke implikacije progona i iseljavanja na primjeru knjige Jeremije proroka, Bosna franciscana, 36 (2018.) 49, 9-43.

- TOMAŠEVIĆ, Darko, Bog nasilja u Starom zavjetu: rat i ratne ideologije u Starom zavjetu, Riječki teološki časopis, 25 (2017.) 2(50), 297-326.

- TURALIJA, Dubravo, King Rehoboam according to the Chronicler (2 Chronicler 11-12), Vrhbosnensia, 20 (2016.) 1, 5-33. 
- TURALIJA, Dubravko, Apokaliptički elementi u Daniela 2-6, Bogoslouska smotra, 87 (2017.) 2, 253-270.

- TURALIJA, Dubravko, Discrepancies between the Masoretic Text and the Septuagint Versions of the Book of Proverbs: a Tempting New Solution, Vrhbosnensia, 21 (2017.) 2, 483-498.

- TURALIJA, Dubravko, Nadahnuće i istinitost Svetoga pisma pozitivni privilegij Biblije, Riječki teološki časopis, 25 (2017.) 2(50), 245-276.

- VIŠATICKI Karlo - ZOVKO, Tihonija, Starozavjetna biblijska bibliografija na hrvatskom jeziku (2011.-2015.), Crkva u svijetu, 52 (2017.) 1, 101-140.

- VIŠATICKI, Karlo, Bog se ljuti - Bog se kaje: starozavjetna promišljanja o srdžbi Božjoj, Bogoslovska smotra, 87 (2017.) 2, 239-251

- ŽUPARIĆ, Drago, Anđeli i demoni u Knjizi o Tobiji, Bogoslovska smotra, 87 (2017.) 2, 287-302.

\section{PRILOZI IZ TJEDNIKA, MJESEČNIKA, BIBLIJA DANAS....}

- $\quad$ BLAŽEVIĆ, Josip, Božje milosrđe u knjizi o Joni, Veritas - glasnik sv. Antuna Padovanskog, 60 (2016.) 1, 26-28.

- ČUTURA, Vlado, Biblijski muškarac - uzor današnjim vođama. Prof. dr. Slavica Dodig, autorica leksikona biblijskih žena i muškaraca, Glas Koncila, 57 (2018.) 15, 6-7.

- FUŽINATO, s. Silvana, Nije dobro da čovjek bude sam“. Čovjek biće odnosa (prema Post 2, 4b-25), Vjesnik Đakovačko-osječke nadbiskupije i Srijemske biskupije, 144 (2016.) 12, 1268-1271.

- FUŽINATO, s. Silvana, "Gdje ti je brat Abel?" (Post 4,1-16)., Biblija danas, 16 (23) (2018.) 2, 3-7.

- FUŽINATO, s. Silvana, Kako oduševiti mlade i odrasle za čitanje Svetoga pisma?, Vjesnik Đakovačko-osječke nadbiskupije $i$ Srijemske biskupije, 146 (2018.) 1, 16-21.

- $\quad$ FUŽINATO, s. Silvana, Sveti budite! Jer sam svet ja, Jahve, Bog vaš! (Lev 19,2). Poziv na svetost u Starom i Novom zavjetu, Vjesnik Đakovačko-osječke nadbiskupije i Srijemske biskupije, 146 (2018.) 9, 992-997.

- GRDEN, Darko, Saveznički odnos Boga. Zemlje i naroda/čovjeka. Dr. Đurica Pardon: Teologija zemlje na temelju metaforike proroka Hošee, Glas Koncila, 56 (2017.) 22, 9.

- GRDEN, Darko, Zemlja je dio „Božjega domaćinstva“. Teologija zemlje na temelju metaforike proroka Hošee (2), Glas Koncila, 56 (2017.) 23, 9. 
- MALY, Anđelo, Roš hašana, Jom kipur i Sukot - Nova godina i Tijelovo, Biblija danas, 16 (23) (2018.) 3, 20-23.

- MARIJANOVIĆ, Luka, Hodočašće u svjetlu Svetoga pisma, Vjesnik Đakovačko-osječke nadbiskupije i Srijemske biskupije, 145 (2017.) 7-8, 793-806.

- ODOBAŠIĆ, Božo, Mesija pravde i mira, Katolički tjednik, 15 (39) (2016.) 51-52, 24-26.

- ODOBAŠIĆ, Božo, Blagdan sedmica - Duhovi, Biblija danas, 16 (23) (2018.) 3, 12-19.

- TEPERT, Darko, Bog bogat milosrđem i nježnošću, Kana, 47 (2016.) 1(505), 30-31.

- $\quad$ TEPERT, Darko, Milosrđe i obraćenje, Kana, 47 (2016.) 2 (506), 28-31.

- $\quad$ TEPERT, Darko, Božje i čovjekovo milosrđe, Kana, 47 (2016.) 3 (507), 28-29.

- $\quad$ TEPERT, Darko, Poučavanje milosrđu, Kana, 47 (2016.) 4 (508), 28-29.

- $\quad$ TEPERT, Darko, Milosrđe će zasjati, Kana, 47 (2016.) 5 (509), 28-29.

- TEPERT, Darko, Siromaštvo kao dobitak, Sujetlo riječi, 34 (2016.) 399, 4-7.

- $\quad$ TEPERT, Darko, Biblija i financije, Kana, 48 (2017.) 5 (520), 28-29.

- $\quad$ TEPERT, Darko, Bog i prirodne nepogode, Kana, 48 (2017.) 10 (524), 28-29.

- $\quad$ TEPERT, Darko, Knjiga po mjeri čovjeka, Svjetlo riječi, 35 (2017.) 406, 11-13.

- $\quad$ TEPERT, Darko, Izgubljene knjige u Starom zavjetu, Svjetlo riječi, 35 (2017.) 407, 11-13.

- TEPERT, Darko, Mojsijev poziv i Božje ime, Svjetlo riječi, 35 (2017.) 412-413, 13-15.

- TEPERT, Darko, Povijest ulaska u obećanu Zemlju, Svjetlo riječi, 35 (2017.) 414, 11-13.

- TEPERT, Darko, Siromasi i siromaštvo u Starom zavjetu, Svjetlo riječi, 35 (2017.) 415, 11-13.

- $\quad$ TEPERT, Darko, Sveti Bog i sveti narod, Svjetlo riječi, 35 (2017.) 416, 11-13.

- $\quad$ TEPERT, Darko, Svi će narodi doći, Kana, 48 (2017.) 2 (517), 26-27.

- $\quad$ TEPERT, Darko, Zašto baš Betlehem?, Svjetlo riječi, 35 (2017.) 417, 12-13. 
- $\quad$ TOMAŠEVIĆ, Darko, Geografija Svete Zemlje, Svjetlo riječi, 34 (2016.) 394, 32-33.

- $\quad$ TOMAŠEVIĆ, Darko, Privlačnost Svete Zemlje, Svjetlo riječi, 34 (2016.) 395, 32-33.

- TOMAŠEVIĆ, Darko, Mrtvo more i Transjordan, Svjetlo riječi, 34 (2016.) 396, 32-33.

- $\quad$ TOMAŠEVIĆ, Darko, Minerali, metali i drago kamenje, Sujetlo riječi, 34 (2016.) 397, 32-33.

- TOMAŠEVIĆ, Darko, Drago kamenje u Svetom pismu, Sujetlo riječi, 34 (2016.) 398, 36-37.

- $\quad$ TOMAŠEVIĆ, Darko, Životinje u Svetom pismu, Svjetlo riječi, 34 (2016.) 400, 32-33.

- $\quad$ TOMAŠEVIĆ, Darko, Koze i konji u Svetom pismu, Svjetlo riječi, 34 (2016.) 401, 30-31.

- TOMAŠEVIĆ, Darko, Magarci i deve u Svetom pismu, Svjetlo riječi, 34 (2016.) 402, 32-33.

- TOMAŠEVIĆ, Darko, Divlje životinje u Svetom pismu, Svjetlo riječi, 34 (2016.) 403, 36-37.

- TOMAŠEVIĆ, Darko, Noviji načini tumačenja tekstova o "nemilosrdnom" i "militantnom" Bogu u Starom zavjetu. Pokušaji tumačenja u svjetlu Još 6-11, Bogoslovska smotra, 86 (2016.) 3, 545-573.

- TOMAŠEVIĆ, Darko, Ptice u životu ljudi iz Biblije, Svjetlo riječi, 34 (2016.) 404, 32-33.

- TOMAŠEVIĆ, Darko, Simbolika i značaj riba u Bibliji, Sujetlo riječi, 34 (2016.) 405, 32-33.

- TURAliJA, Dubravko, Moapski geni kralja Davida, Biblija danas, 16 (23) (2018.) 4, 3-5.

- VELČIĆ, Bruna, Čovjek - muškarac i žena - u drugom izvještaju o stvaranju (Post 2,4b-25), Biblija danas, 16 (23) (2018.) $1,8-13$

- VELČIĆ, Bruna, Pasha - Uskrs, Biblija danas, 16 (23) (2018.) 3, 9-11.

- VIŠATICKI, Karlo, Prijevod Svetog pisma Matije Petra Katančića, Biblija danas, 15 (22) (2017.) 2, 14-17.

- VIŠATICKI, Karlo, Samuel i Davidovo pomazanje, Biblija danas, 16 (33) (2018.) 4, 6-9. 


\section{OLD TESTAMENT BIBLE BIBLIOGRAPHY (2016-2018)}

\section{Summary}

The contribution presents, with few exceptions, the Old Testament bibliography in Croatian language. This is a continuation of similar contributions that were published in the journal "Crkva $\mathrm{u}$ Svijetu" in 2016. The years 2016, 2017 and 2018 are covered. In this first part of the Old Testament section, the bibliography of a total of fifteen (15) journals is provided, as well as dictionaries, editions of the Scripture, commemorative editions of the Bible, monographs, several editions of sermons which by their nature contain biblical themes. Proceedings, as well as some contributions in the proceedings, are listed in alphabetical order of the author's surname. Contributions from professional journals of a scientific character are included (A1 and A2), as well as the contributions from weeklies and monthlies with a more devulgative character. The contribution is divided into nine (9) sections and brings: 1) dictionaries ( $2 \mathrm{x})$; 2) editions of the Scripture (7x); 3) commemorative editions of the Bible (12x); 4) fourteen (14) monographs by nine (9) authors; 5) four (4) collections of sermons by three (3) authors; 6) nineteen proceedings containing 7) fifty (50) contributions by thirty six (36) authors. Finally, we have: 8) contributions from professional journals of a scientific character i.e. thirty three (33) contributions by nineteen (19) authors, and 9) forty five (45) contributions from the weekly, monthly, "Biblija Danas", from the journal of devulgative character by twelve (12) authors The purpose of the contribution is to help colleagues in the profession, as well as anyone who appreciates the written Word of God, to reach easily and quickly the contents published in the last three (3) years.

Key words: Bible, Old Testament, Biblical Bibliography, Old Testament Bible Bibliography, Croatian Bible Bibliography 